\title{
Analysis of Inflow Solutions among Eleven Sewer Systems
}

\author{
Frederick Bloetscher (1) \\ Department of Civil, Environmental and Geomatics Engineering, Florida Atlantic University, Boca Raton, FL, USA \\ Email: fbloetsc@fau.edu
}

How to cite this paper: Bloetscher, F. (2021). Analysis of Inflow Solutions among Eleven Sewer Systems. Journal of Geoscience and Environment Protection, 9, 64-86. https://doi.org/10.4236/gep.2021.99005

Received: June 12, 2021

Accepted: September 20, 2021

Published: September 23, 2021

Copyright $\odot 2021$ by author(s) and Scientific Research Publishing Inc. This work is licensed under the Creative Commons Attribution International License (CC BY 4.0).

http://creativecommons.org/licenses/by/4.0/

(c) (i) Open Access

\begin{abstract}
This paper was undertaken to compare eleven utilities where part or all of the utility was tested for infiltration and inflow with the intention of determining the value of data gathered from midnight investigations, comparing potential costs (in 2020 dollars), and understanding whether statistical methods can be used to predict potential problems on the system. Inflow and infiltration amounts can be identified on a utility system without significant effort. Inflow correction is robust and easy to implement (though often overlooked). After inflow is addressed, the results indicated that a midnight investigation could quickly identify portions of the sewer system in need of attention. Maps of leaky pipe sections can be identified, and commonalities in the system may become apparent. Statistical methods were used to identify high groundwater levels and lateral issues as critical issues on these systems. The methods can be utilized at other utilities to help guide them to addressing the critical issues first as opposed to focusing only on the traditional pipe lining solutions that often ignore the lateral and inflow issues that plague utility managers.
\end{abstract}

\section{Keywords}

Inflow, Sanitary Sewer, Overflow, Rainfall, Groundwater, Infiltration

\section{Introduction}

The initial goal of the Clean Water Act was to restore the nation's rivers and streams to their highest and best use through the removal of untreated industrial and domestic wastewaters. Prior to legislation passed as the Federal Water Pollution Control Act in 1948, many municipalities discharged wastes directly to the nearby waterways, which were often water supplies for those downstream, through extensive gravity systems. To resist the chemical concerns in wastewater, the pipes, from pre-1900 through the 1980s, were primarily vitrified clay. In 
many cases the stormwater and sanitary sewer systems were one, especially in the northeast and Great Lakes states.

Vitrified clay pipe has a long service life when installed correctly and left undisturbed, but is brittle, so surface vibrations, freeze/thaw cycles and poor construction methods (indicated by settling from incorrect pipe bedding) will cause these pipes to fail in time, primarily by cracking. Short joints make for many potential openings in the pipe which are exacerbated by the fact that the temperature differences between the warm wastewater and cooler soils cause exterior pipe sweating which encourages tree roots to migrate to the pipe and enter the joints. The majority of domestic wastewater facilities operated by one of the over 16,000 sewer utilities in the United States, operate in this environment where pipes are old, money is scarce and investments have not been made. Keeping the sewer system operating comes at a cost that is not well understood by local government officials or the public. Compounding the problem is that by their very nature, buried pipes and protected facilities are out of the public view. The lack of obvious problems or critical failures generally leads the public and local officials to believe the sewer infrastructure to be "ok" as it is (Bloetscher, 2008, 2011). But ongoing maintenance of the sewer system can yield cost savings in operations, starting with power costs.

(Lisk et al., 2012) reported that $4 \%$ of the total power produced In the United States, is used by water and wastewater systems, mostly to pump water. In sanitary sewer systems, pumping can be as much as $90 \%$ of the total power used (Lisk et al., 2012). Substantial savings in operations can be achieved by preventing the water that is not wastewater from entering the piping system. The key to reduction in power, is the reduction in water pumped, which means keeping water out of the sewer system. However, there is a general lack of understanding of the components of the water entering the system, which makes solving the problem difficult, and therefore securing funding a challenge.

Figure 1 shows all the areas where water can get into the collection system. There is inflow, which is water off the surface during and after rainstorms which creates hydraulic issues that can lead to sanitary sewer overflows (SSOs) and subject the utility to fines from regulatory agencies and lawsuits from residents. (Wingard, 2015) reported that inflow can contribute $90 \%$ of flows into the sanitary sewer system during storm events. Fort Lauderdale, Florida has faced significant challenges with this problem in the past 2 years (Bryan, 2020, 2020a; Marcus, 2020). In contrast, infiltration is seeping groundwater that enters the piping underground constantly. Closed-circuit television (CCTV) is the most common assessment tool conducted by municipalities to determine the presence of roots, leaks, debris, and flow conditions (USEPA, 2005). Unfortunately, even operators and professional engineers often lump infiltration and inflow together as one.

The question to answer with this investigation was whether:

- Inflow could be estimated pump run time data;

- Infiltration could be estimated using run time data; 


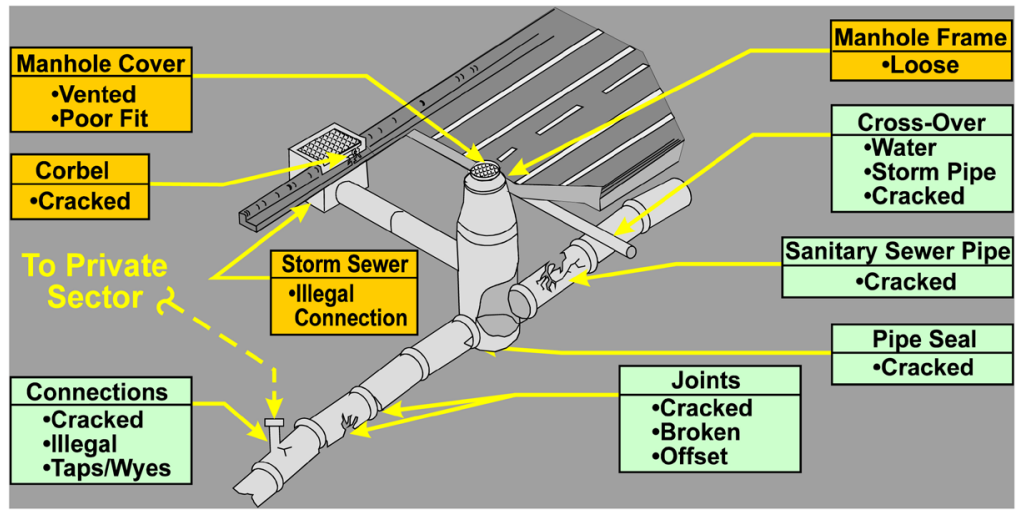

Rain and High Groundwater Affects

Wastewater Collection System

Figure 1. Entry points for infiltration and inflow (Bloetscher, 2019).

- Inflow methods would work;

- Leaky pipes could be identified;

- Similar systems could point to similar defects.

\section{Methodology}

Utilities know they have an inflow problem, and not an infiltration problem, when flows increase when it is raining. Figure 2 shows a typical graph of rainfall versus flow for a utility. Collection of lift station run times can indicate the stations with the most significant issues when run times are plotted against rainfall. Infiltration can be found by plotting rainfall against groundwater. It was assumed that inflow into sanitary sewer lines is linearly related to rainfall (Merrill, 2004), and that infiltration is linearly related to groundwater elevation. Basic statistical graphing methods can be used to derive these quantities.

A regression analysis was used because it focuses on understanding how the dependent variable (inflow) changes, as the independent variable (rainfall) is varied. Once the linear relationship between rainfall and inflow was determined, any rainfall could be entered into the regression analysis to determine the associated inflow value. Inflow can then be separated from the total flows. Once the inflow values were separated, the relationship between groundwater elevation values and run-times was determined through a second regression exercise. It was assumed that fluctuations in baseflow were negligible from day to day.

To develop an analysis of sewer system issues, data from eleven utility systems investigated were compiled. The utility systems that are partially or fully used in the analysis are in coastal south Florida (Dania Beach, Pinellas, Davie, Hallandale Beach), inland communities (Clewiston, Orlando, Toho Water Authority, Madison), and the Brunswick Joint Water-Sewer Commission in southeast Georgia. Table 1 outlines the characteristics of the communities. Five are coastal. Vitrified Clay pipe is the primary pipe type most of the system.

In addition, PCA and regression analyses were utilized. The Principal Component Method (PCA) has been used to extract the independent factors using 
Table 1. Utility systems included (Bloetscher, 2009, 2015, 2017a, 2017b, 2017c, 2018a, 2018b, 2018c, 2019, 2020a, 2020b).

\begin{tabular}{|c|c|c|c|c|c|c|c|c|c|c|c|}
\hline Location & $\begin{array}{c}\text { Manholes } \\
\text { in areas } \\
\text { studied }\end{array}$ & $\begin{array}{c}\text { Smoke } \\
\text { Test/Lateral } \\
\text { Leaks }\end{array}$ & $\begin{array}{l}\text { Est. Total } \\
\text { Pipe in Area } \\
\text { studied }\end{array}$ & $\begin{array}{l}\text { Pipe to } \\
\text { review per } \\
\text { Midnight } \\
\text { Run }\end{array}$ & $\begin{array}{l}\text { Percent } \\
\text { pipes } w \\
\text { Leaks }\end{array}$ & $\begin{array}{l}\text { infiltration } \\
\text { Est Flow } \\
\text { (gpm) }\end{array}$ & $\begin{array}{c}\text { Relative } \\
\text { Age } \\
\text { of Pipe }\end{array}$ & $\begin{array}{l}\text { Pipe } \\
\text { Type }\end{array}$ & $\begin{array}{l}\text { Prior } \\
\text { Lining }\end{array}$ & $\begin{array}{l}\text { Water } \\
\text { Table }\end{array}$ & Topography \\
\hline $\begin{array}{c}\text { Hallandale } \\
\text { Beach }\end{array}$ & 1097 & 276 & 274,000 & 96,000 & $35 \%$ & 1400 & $60 \mathrm{~s}$ & $\mathrm{VC}$ & yes & High & Flat/Coastal \\
\hline Dania Beach & 797 & 567 & 199,250 & 45,000 & $23 \%$ & 800 & $60 \mathrm{~s} / 70 \mathrm{~s}$ & $\mathrm{VC}$ & yes & High & Flat/Coastal \\
\hline Davie & 920 & $\mathrm{n} / \mathrm{a}$ & 230,000 & 43,000 & $19 \%$ & 1350 & $70 \mathrm{~s} / 80 \mathrm{~s}$ & VC/PVC & yes & Medium & Flat/Coastal \\
\hline Clewiston & 814 & 281 & 203,500 & 83,000 & $41 \%$ & 500 & 70 & $\mathrm{PVC} / \mathrm{VC}$ & no & High & Inland \\
\hline $\begin{array}{l}\text { Brunswick } \\
\text { JWSC }\end{array}$ & 1921 & 254 & 480,250 & 70,000 & $15 \%$ & 350 & $50 \mathrm{~s} / 60 \mathrm{~s}$ & VC & yes & High & Flat/Coastal \\
\hline Madison & 442 & $\mathrm{n} / \mathrm{a}$ & 110,500 & 18000 & $16 \%$ & 100 & $60 \mathrm{~s}$ & VC & no & Low & Inland \\
\hline Orlando & 278 & $\mathrm{n} / \mathrm{a}$ & 69,500 & 20,000 & $29 \%$ & 400 & $60 \mathrm{~s}$ & $\mathrm{VC}$ & yes & Medium & Inland \\
\hline $\begin{array}{c}\text { Toho Water } \\
\text { Authority }\end{array}$ & 767 & $\mathrm{n} / \mathrm{a}$ & 191,750 & 52,000 & $27 \%$ & 325 & $70 \mathrm{~s} / 80 \mathrm{~s}$ & VC & yes & High & Inland \\
\hline $\begin{array}{l}\text { Pembroke } \\
\text { Pines }\end{array}$ & 713 & 410 & 178,250 & 24,000 & $13 \%$ & 200 & $60 \mathrm{~s} / 70 \mathrm{~s}$ & VC/PVC & yes & High & Flat/Coastal \\
\hline $\begin{array}{c}\text { Gainesville } \\
\text { Regional }\end{array}$ & 688 & $\mathrm{n} / \mathrm{a}$ & 172,000 & 53,000 & $31 \%$ & 1700 & $60 \mathrm{~s}$ & VC & yes & low & Inland \\
\hline Pinellas & 72 & 0 & 18,000 & 10,000 & $56 \%$ & 1 & $60 \mathrm{~s}$ & $\mathrm{VC}$ & No & High & Flat/Coastal \\
\hline
\end{tabular}

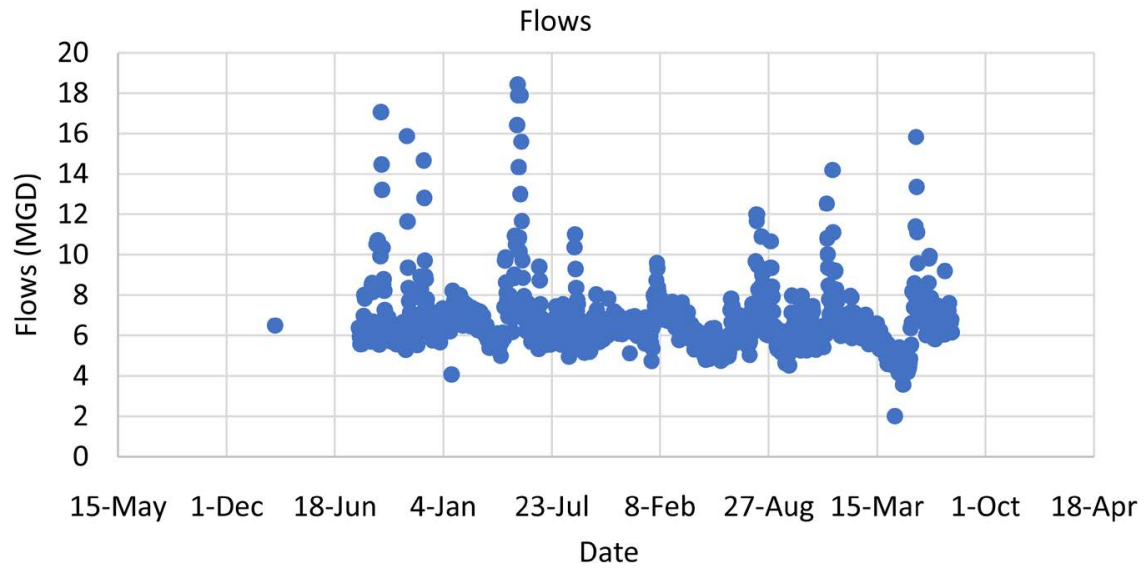

Figure 2. Example of system with inflow issues.

the eigenvalues (potted as a Scree plot). The eigenvalues indicate the variance included in each principal factor. The goal is to reduce the number of variable by combining factors that are highly correlated. In addition, the rotation phase of factor analysis attempts to transform the initial matrix into one that is easier to interpret. Varimax rotation has been used in this research to improve results' analysis and interpretability.

Linear regression is a probabilistic statistical technique that models a rela- 
tionship between one or more explanatory variables (or independent variables) of observed data to predict a condition. In this case, critical query was whether a high water table or lateral issues could be predicted. Because so many of the variables were categorical, logistic regression was used as well and compared. Logistic regression is a probabilistic statistical technique to predict the outcome of a dichotomous variable based on one or more predictor variables. Logistic regression better uses categorical variables than linear regression and since some of the variables are dichotomous, this analysis was also conducted.

\section{Results}

Figure 2 showed a typical graph of flow for a south Florida wastewater plant. It can be seen that there are some very high peaks. If the peaks correlate with rainfall, there is an inflow problem. For this system, a scan of the South Florida Water Management District's DBHydro data base indicated two rainfall stations that might be of help. The sites are NSID1_R and G56-R (see Figure 3). The NCSID site stopped recording in 2019. Figure 4 shows a graph of rainfall versus flow. The peaking that correlates with the rainfall is inflow. The amount of inflow can be calculated. The data indicates that without inflow, the average daily flow is about 6.6 MGD (see Figure 5).

As noted in Figure 1, there are many ways water gets into the pipes from the surface. Resolving inflow issues is straightforward and flows a set of basic steps. The order is important and pursuing all steps will resolve the majority of issues.

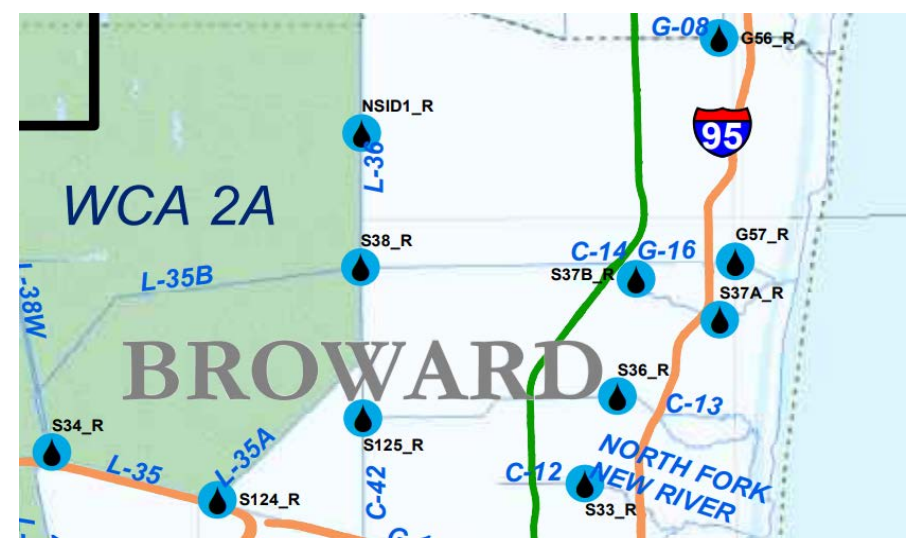

Figure 3. DBHydro map of rain gages in broward county.

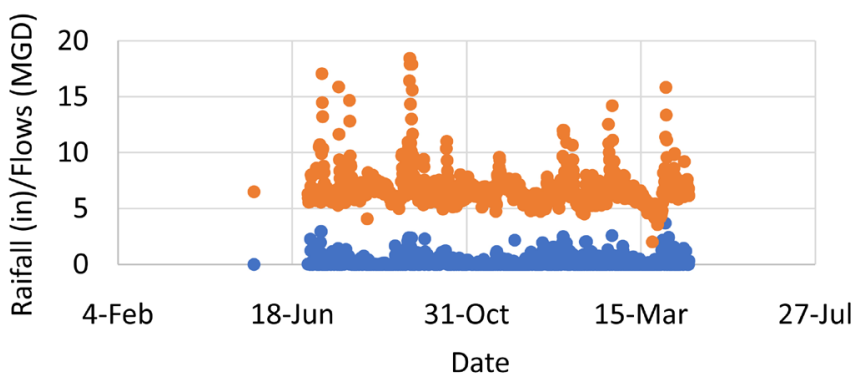

Figure 4. Comparison of rainfall and flows for a South Flroida utility. 


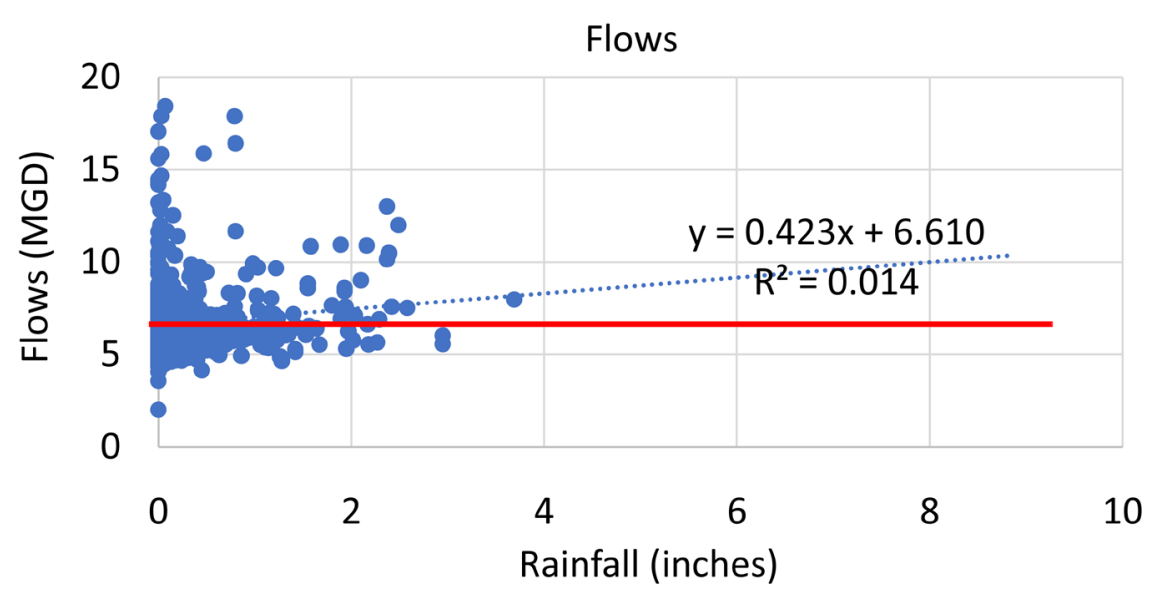

Figure 5. Comparison of rainfall versus flows for a South Florida utility.

The first step is an inspection of all sanitary sewer manholes for damage, leakage or other problems. The manhole inspection should include documentation of condition, GPS location, and some form of numbering if not currently available. Manhole inspections can also document useful information like excessive grease build-ups, improper disposal of feminine hygiene products, wipes, and other trash flushed by customers (Stratton-Childers, 2015). Options to reduce this problem include trash cans, access to towels and wipes in restrooms, bidets and systems like the Heinie-Genie (Rabines, 2015), but none of these are convenient away from home. Once the manhole inspection is undertaken there are four steps that follow:

- Repair/sealing of chimneys in all manholes to reduce inflow from the street during flooding events (see Figure 6).

- Install manhole dishes with ribs and gaskets into the manholes (see Figure 7). The need for the gasket is based on data Miami Dade County gathered in 2010: 1) Rate with no inflow dish: 5.45 GPM; 2) Rate with inflow dish with no gasket: 0.72 GPM; 3) Rate with Inflow Defender inflow dish: 0.002 GPM.

- Smoke testing can identify obvious surface connections (see Figure 8 and Figure 9). The normal notifications, inspection and documentation will identify broken or missing cleanout caps, surface breaks on public and private property, connection of gutters to the sewer system, and stormwater connections.

- Fix the public openings at cleanouts can be corrected immediately including installation of something like the LDL plug (see Figure 10 and Figure 11).

Figures 12-14 demonstrate the before and after flows for lift stations that were identified as among the worst in three separate utility systems. The graphs show that the flow did not increase with rainfall after the inflow corrections were made except in Figure 15, which was found to be caused by another service area that was not inflow corrected, something the community was not aware of. As a result, the relationship between rainfall and flow could be established as an equation and the amount deducted from the daily flows. 


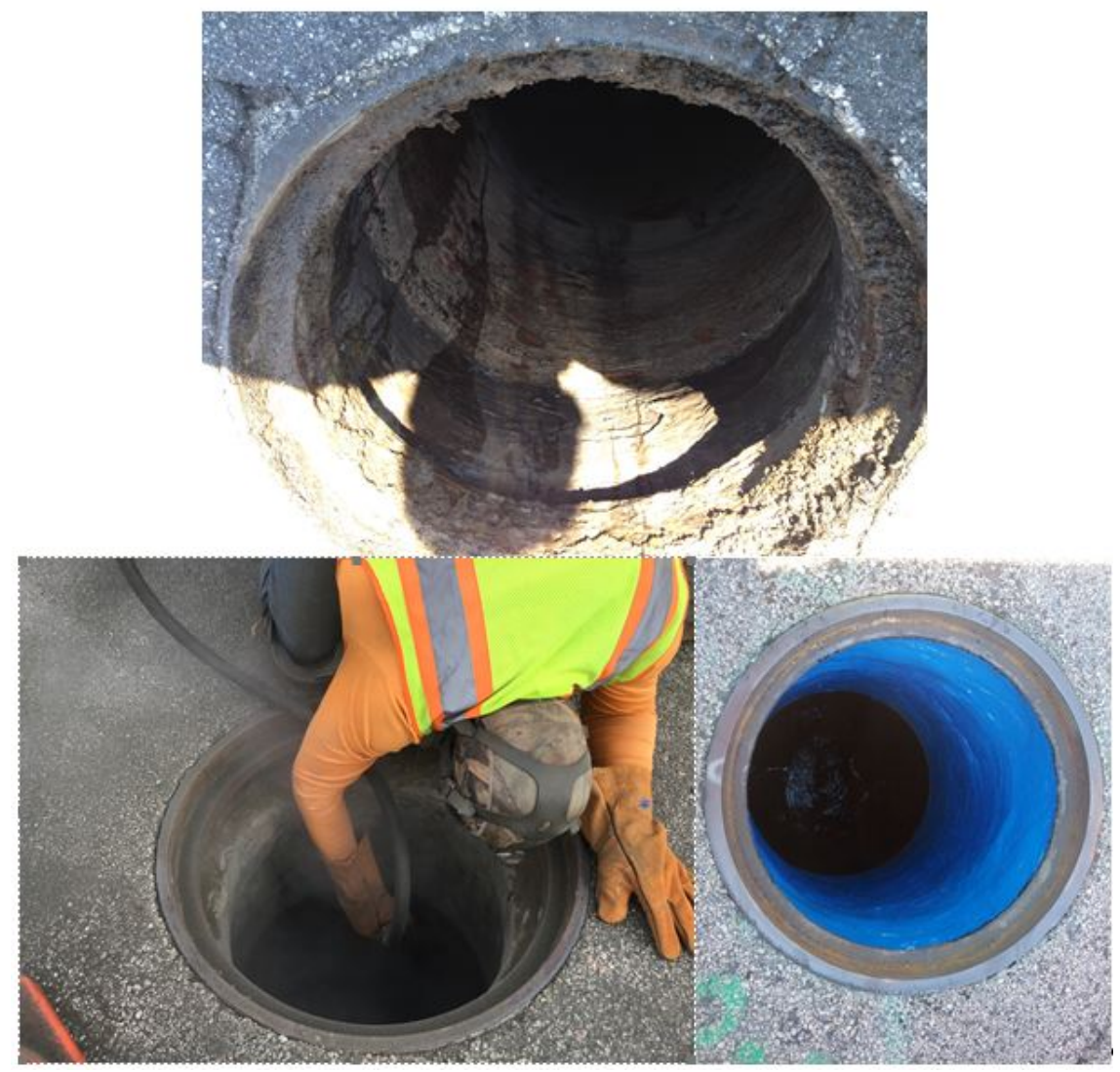

Figure 6. Installation procedure (courtesy, USSI, Inc.).
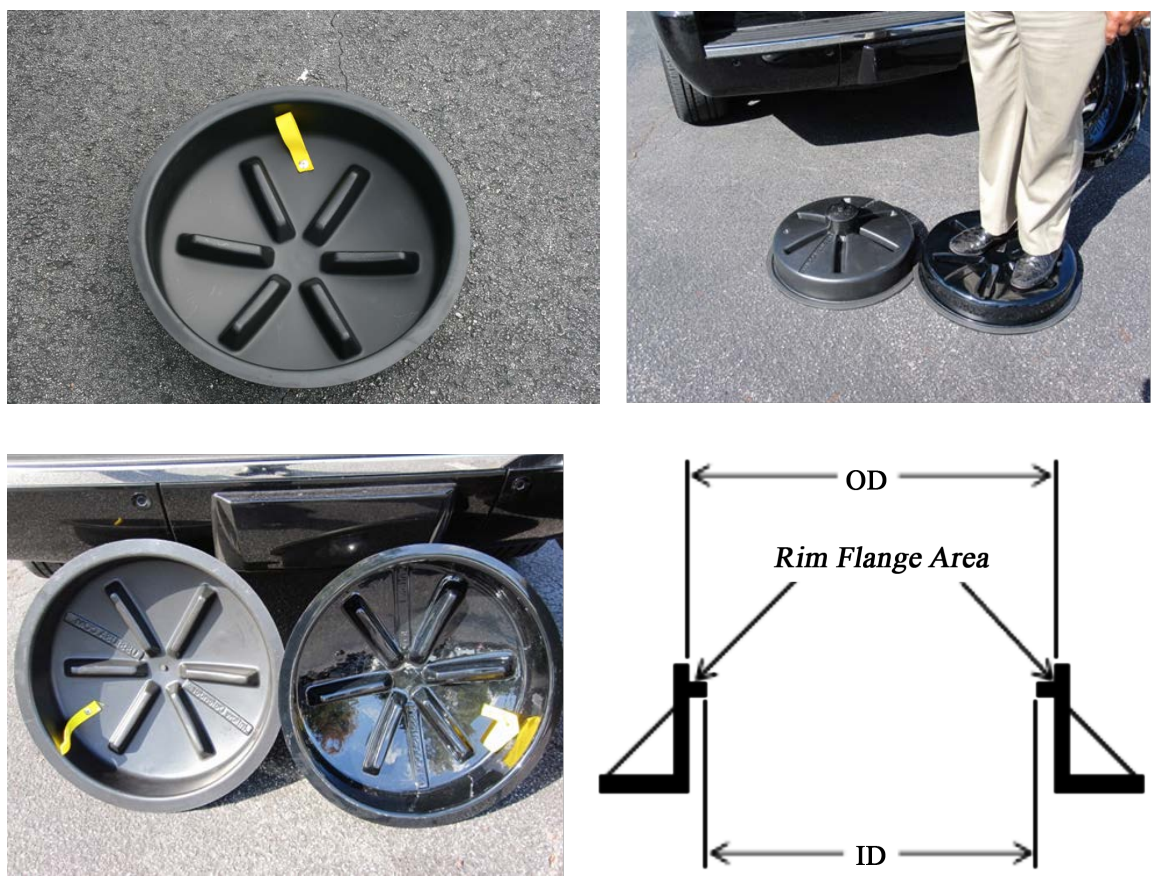

Figure 7. Inflow defender manhole rain dish showing installed dish, and both polycarbonate and polyethylene versions. ${ }^{\star}$ Note the ribs and depth of dish that improves long-term strength. Note polycarbonate is required for newer, 30 or 48 inch manhole (Courtesy, USSI, Inc. (Bloetscher, 2011)). 

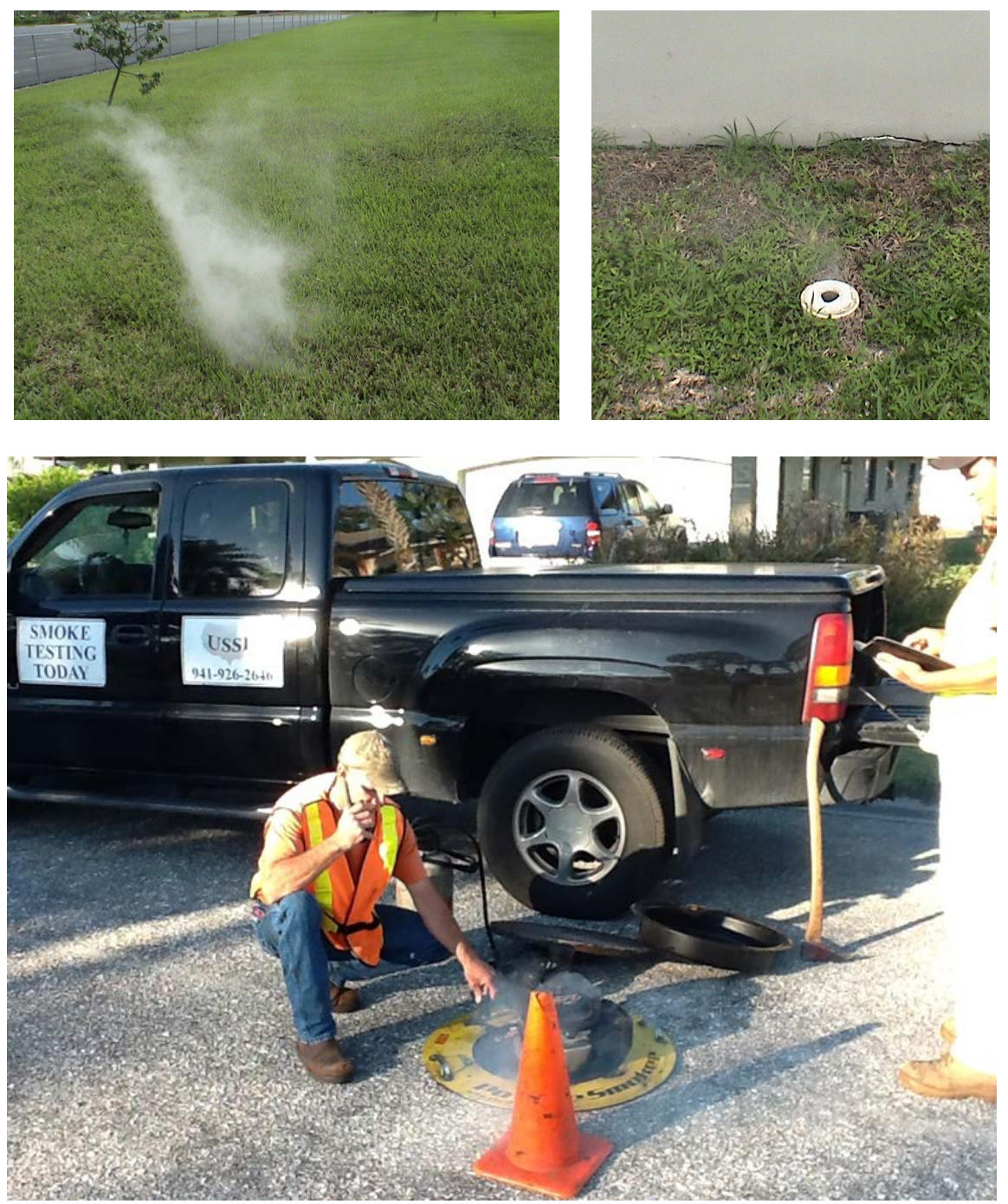

Figure 8. Smoke test results.

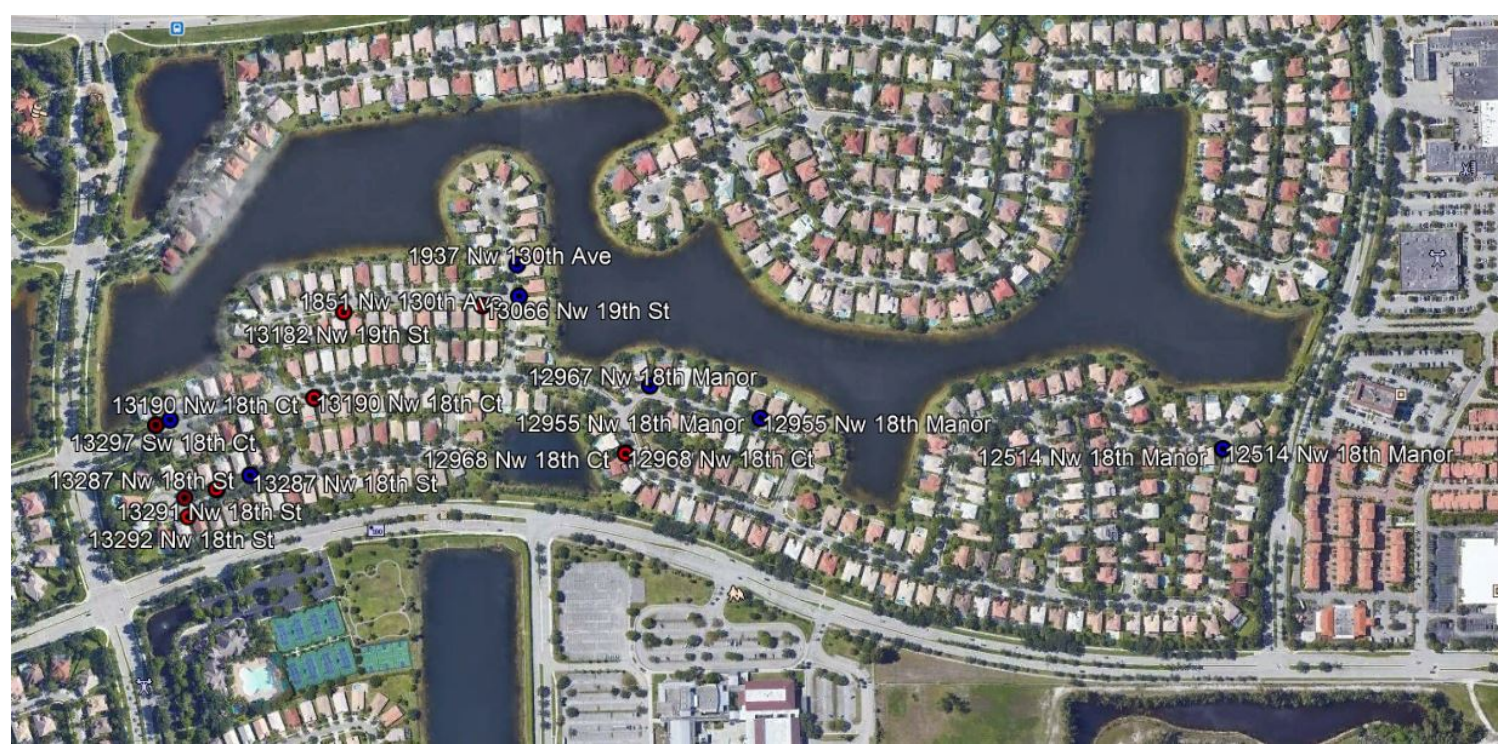

Figure 9. Smoke test results for LS area. 


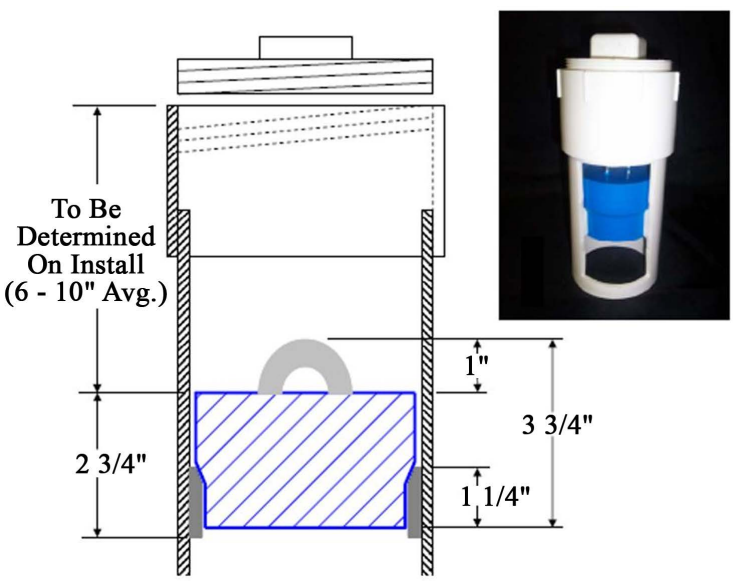

Figure 10. LDL plug design (courtesy, USSI, Inc. (Bloetscher, 2011)).

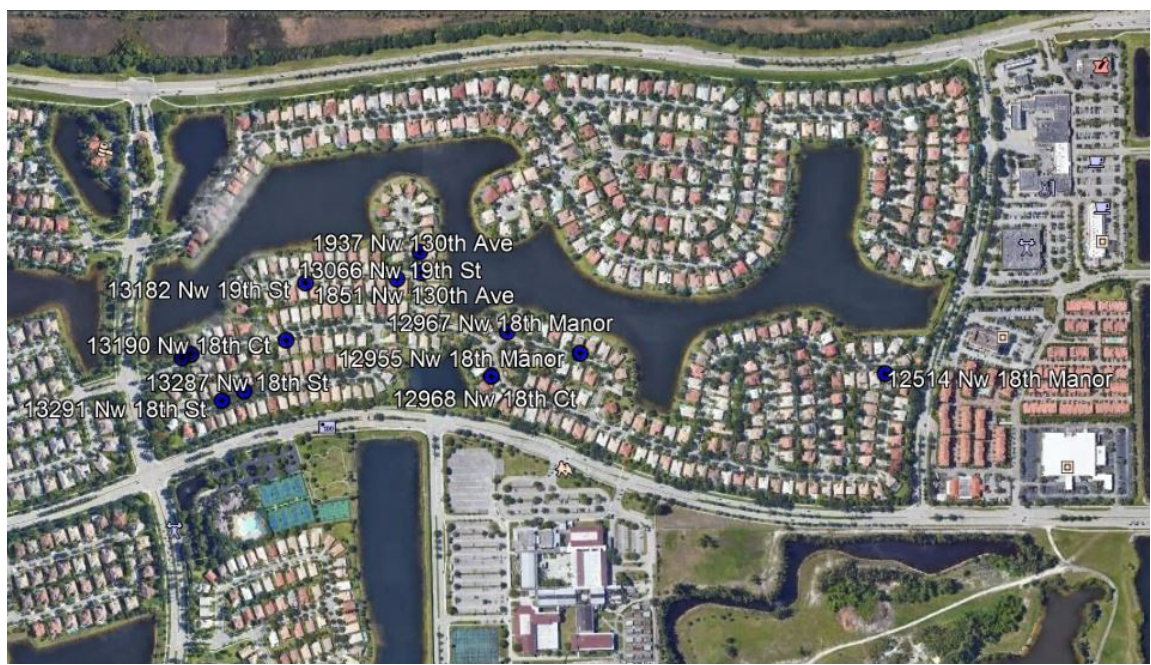

Figure 11. LDL plug installation locations in LS area 130 (Pembroke Pines).

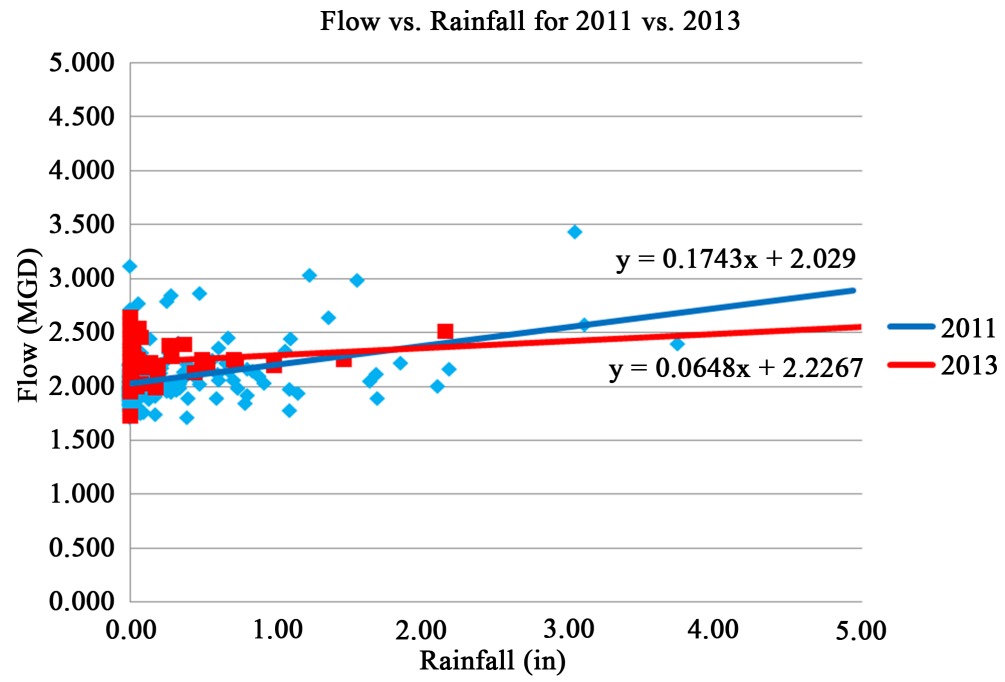

Figure 12. Comparison of rain events (inches) versus pump run times in 2011 and 2013 for Dania Beach-total community flows. The slope of the lines shows that the inflow correction reduced inflow. 


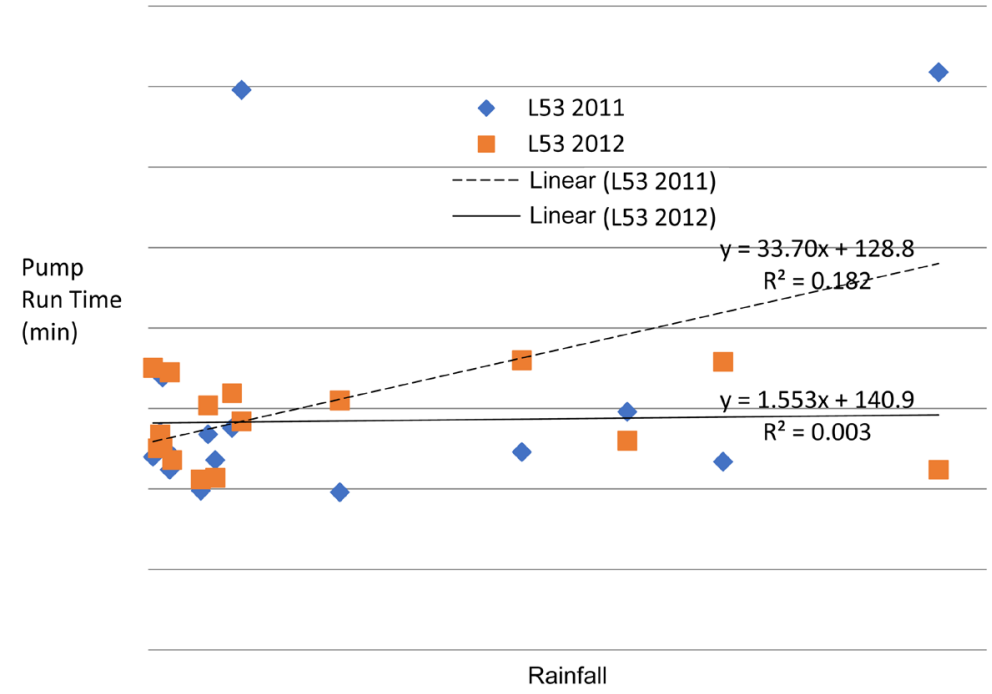

Figure 13. Comparison of rain events (inches) versus pump run times in 2011 and 2012 for cooper city lift station 53 . The 2012 graph shows virtually no effect of rainfall on run times.

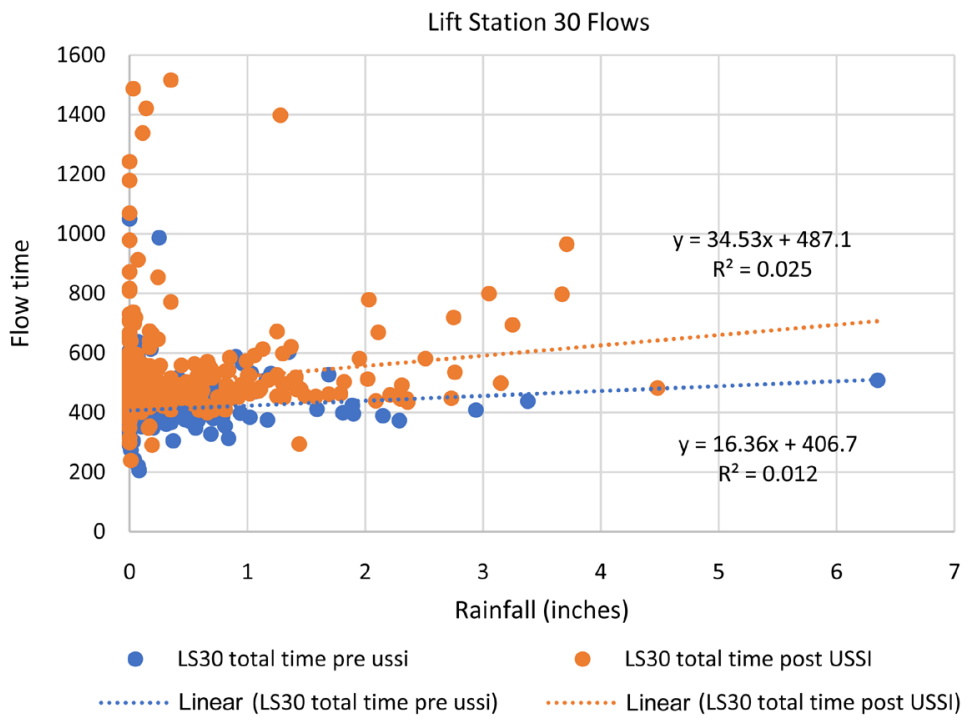

Figure 14. Comparison of rain events (inches) versus pump run times in 2018 and 2020 for Pembroke Pines Lift Station 30. The slope of the lines shows that the inflow correction reduced inflow.

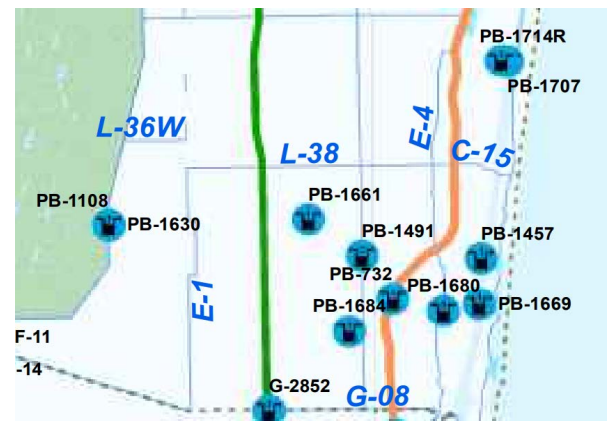

Figure 15. DBHydro locations for Groundwater monitoring. 
Once the inflow was removed, the remainder is infiltration. Figure 16 shows the locations of groundwater stations from DBHydro. Using Stations PB-1630 and PB-1661, Figure 16 shows the relationship between groundwater and flows. Figure 17 shows that if minimal groundwater is used, the City's flows should be about 4.6 MGD. Infiltration was estimated to be 2 MGD in the utility given their current average flows are 6.6 MGD (see Figure 18). However, where the infiltration was required another step.

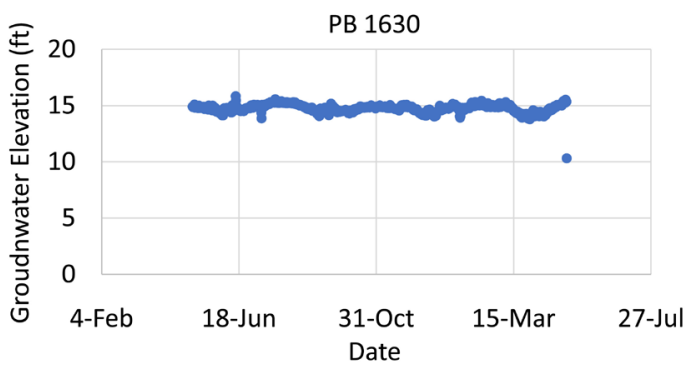

Figure 16. Inflow removed from the Base flows + Infiltration.

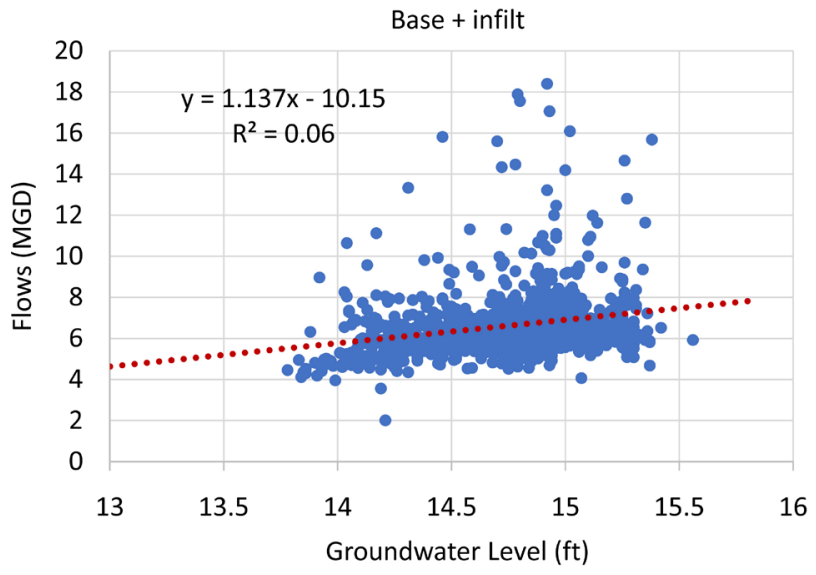

Figure 17. Flows versus groundwater.

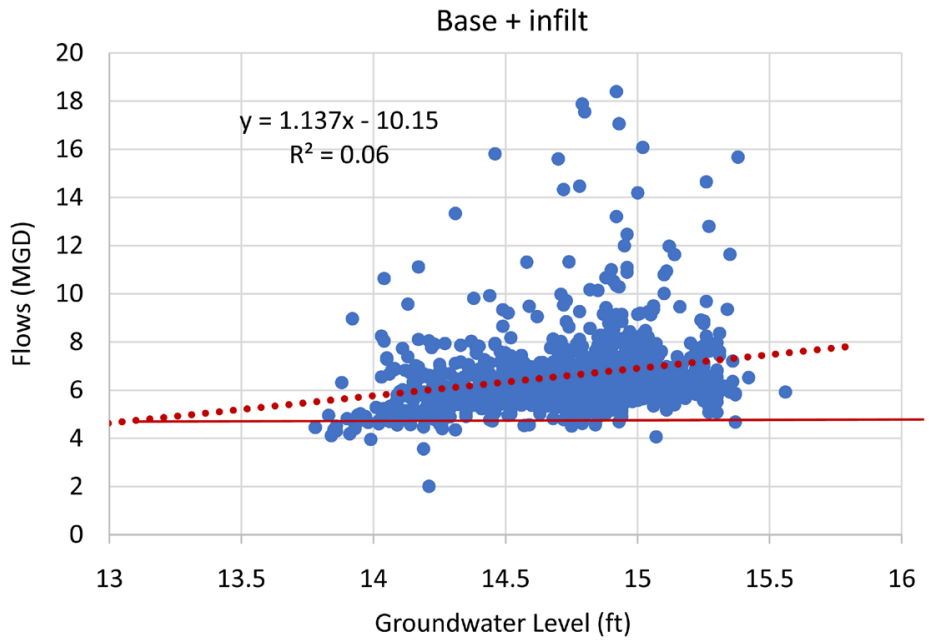

Figure 18. Flows versus groundwater showing about 1.5 MGD of infiltration. 
As many utilities struggle with funding, identifying the pipes that were most likely to yield results was needed as opposed to videotaping miles of pipe that is not leaking. Therefore, the next step should be a low flow or midnight investigation, which is intended to target the location of infiltration in the piping system. The lowest best time for such analysis occurs from $1 \mathrm{AM}$ to $5 \mathrm{AM}$ when people are sleeping and not using water. Such an event will take several days and must be planned to determine priority manhole to start with and sequencing.

The results can be tabulated and plotted in GIS (see Figures 19-21 for examples). Typically, only 15 to 25 percent of the system has identifiable leaks resulting from the midnight investigation (results from 13 systems). Table 2 outlines the costs (in 2020 dollars) estimated to complete the effort to this point and typical issues noted for each system (adjusted because work was completed from 2005 to 2021). It should be noted that contrary to the concept of televising the entire sewer system, the midnight run creates substantial savings to each system by not televising piping that has minimal defects (last column in Table 2). Table 3 summarizes the costs for inflow removal and the issues found in the sewer system as a part of the midnight investigation.

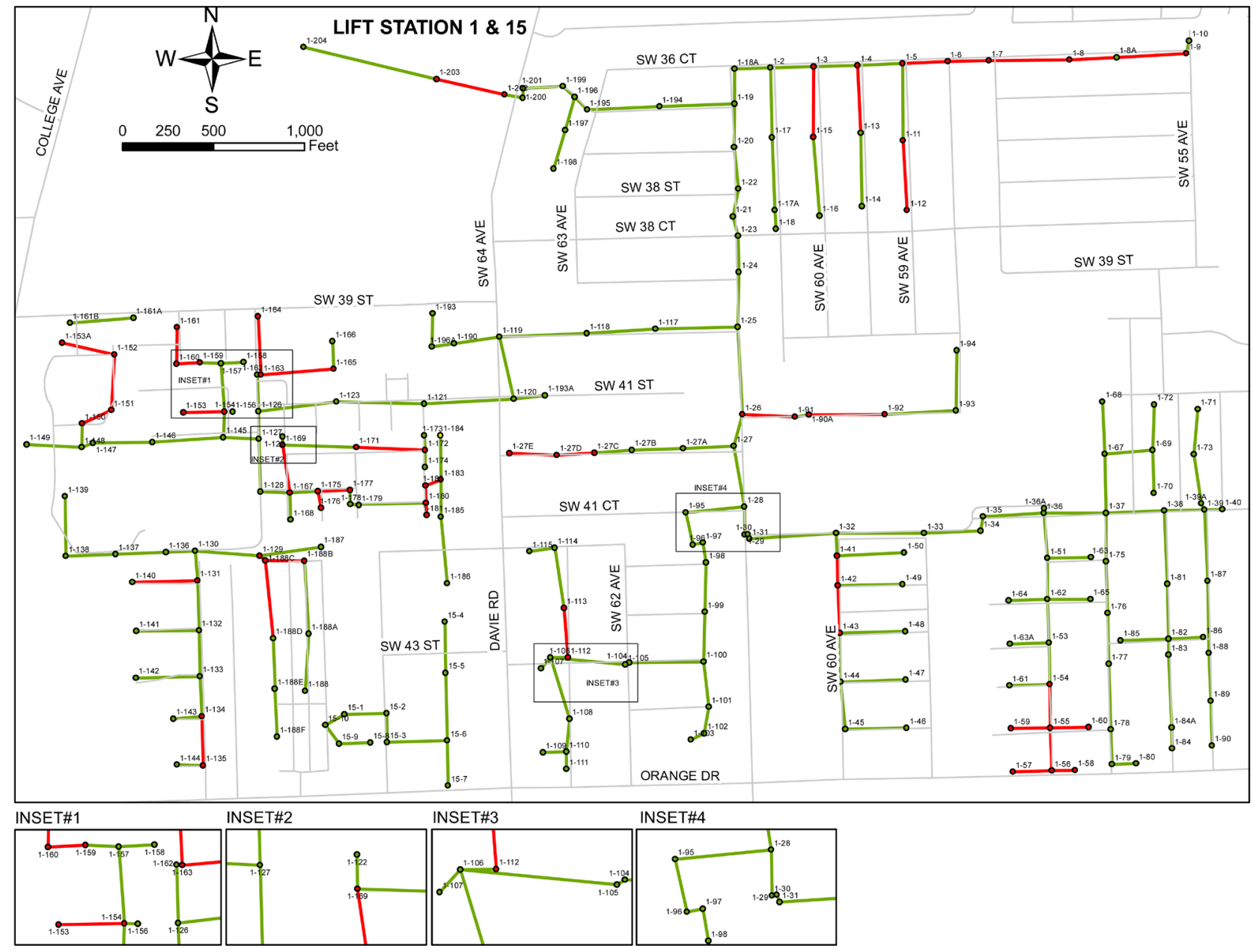

Figure 19. Typical GIS output for Midnight Investigation 15\% - 20\% of pipe contribute most of the infiltration. 


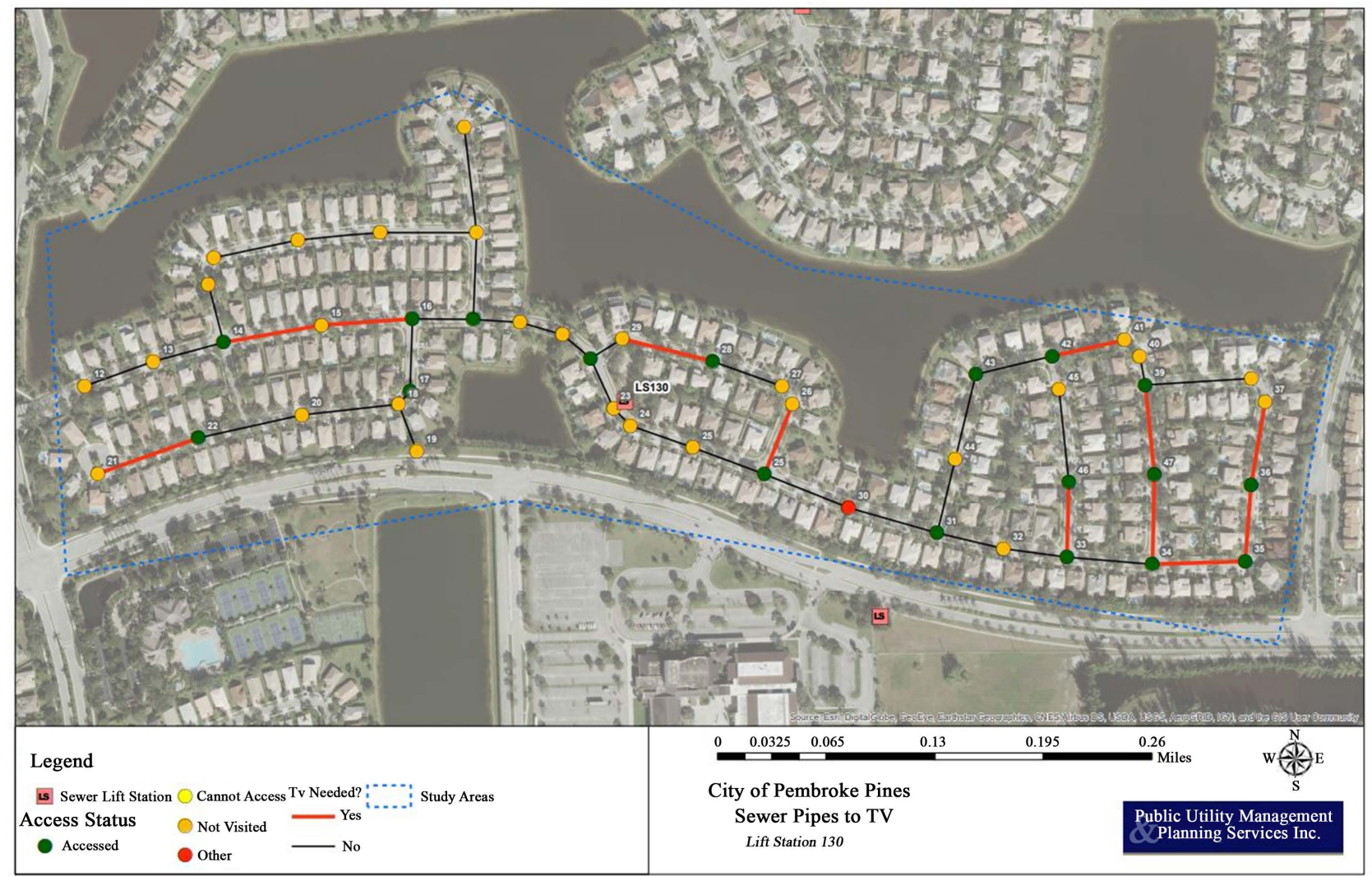

Figure 20. Locations of pipe that appeared to be leaking in LS Area 130 based on midnight investigation.

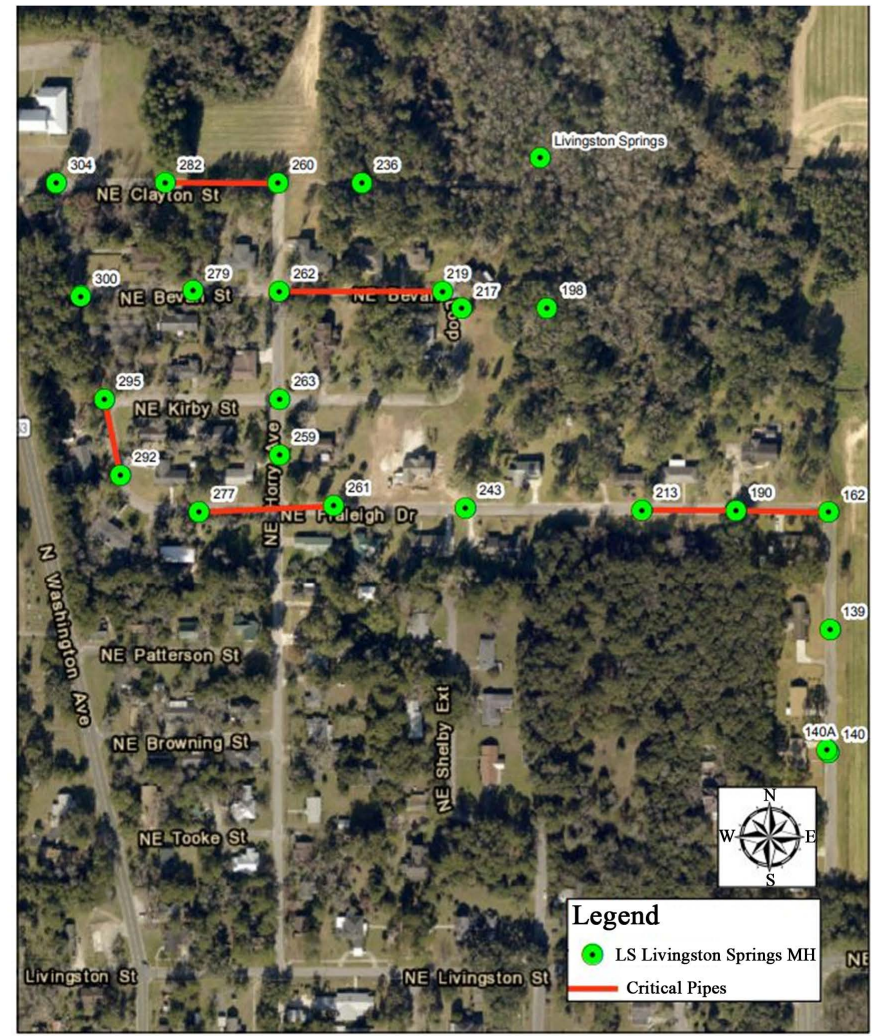

Figure 21. Area 204 red lines show pipes that indicated leakage. 
Table 2. Summary of investigation results.

\begin{tabular}{cccc}
\hline Location & Water Table & Inflow Investigation Costs (2020 dollars est) & Issues noted \\
\hline Hallandale Beach & High & $\$ 430,680$ & grease, sand, liner leaks \\
Dania Beach & High & $\$ 349,598$ & grease \\
Davie & Medium & $\$ 338,100$ & grease, paper \\
Clewiston & High & $\$ 327,245$ & trash, paper \\
Brunswick JWSC & High & $\$ 731,368$ & lateral leak \\
Madison & Low & $\$ 162,435$ & deep clay, Brick MH \\
Orlando & Medium & $\$ 102,165$ & Prior repairs \\
Toho Water Authority & High & $\$ 281,873$ & Laterals cut, brick damage \\
Pembroke Pines & High & $\$ 303,028$ & access issues, lateral leaks \\
Gainesville Regional & low & $\$ 252,840$ & Grease \\
Pinellas & High & $\$ 26,460$ & 4 major sand leaks \\
\hline
\end{tabular}

Table 3. Inflow correction cost.

\begin{tabular}{|c|c|c|c|c|c|c|c|c|c|}
\hline Location & $\begin{array}{c}\text { Manholes } \\
\text { in areas } \\
\text { studied }\end{array}$ & $\begin{array}{c}\text { Manhole } \\
\text { sealing + Dish } \\
\text { Est } \$ 300\end{array}$ & $\begin{array}{c}\text { Smoke } \\
\text { Test/Lateral } \\
\text { Leaks }\end{array}$ & $\begin{array}{l}\text { LDL Plug } \\
\text { Est } \$ 100\end{array}$ & $\begin{array}{l}\text { Est. Total } \\
\text { Pipe in } \\
\text { Area } \\
\text { studied }\end{array}$ & $\begin{array}{c}\text { Smoke } \\
\text { Test Cost }\end{array}$ & $\begin{array}{c}\text { Inflow } \\
\text { Investigation } \\
\text { Costs (2020 } \\
\text { dollars est) }\end{array}$ & $\begin{array}{l}\text { Pipe to } \\
\text { review per } \\
\text { Midnight } \\
\text { Run }\end{array}$ & $\begin{array}{c}\text { Clean }+\mathrm{TV} \\
\text { costs saved } \\
\text { w Midnight }\end{array}$ \\
\hline Hallandale Beach & 1097 & $\$ 329,100$ & 276 & $\$ 27,600$ & 274,000 & $\$ 73,980$ & $\$ 430,680$ & 96,000 & $\$ 726,000$ \\
\hline Dania Beach & 797 & $\$ 239,100$ & 567 & $\$ 56,700$ & 199,250 & $\$ 53,798$ & $\$ 349,598$ & 45,000 & $\$ 552,750$ \\
\hline Davie & 920 & $\$ 276,000$ & $\mathrm{n} / \mathrm{a}$ & & 230,000 & $\$ 62,100$ & $\$ 338,100$ & 43,000 & $\$ 647,000$ \\
\hline Clewiston & 814 & $\$ 244,200$ & 281 & $\$ 28,100$ & 203,500 & $\$ 54,945$ & $\$ 327,245$ & 83,000 & $\$ 527,500$ \\
\hline Brunswick JWSC & 1921 & $\$ 576,300$ & 254 & $\$ 25,400$ & 480,250 & $\$ 129,668$ & $\$ 731,368$ & 70,000 & $\$ 1,370,750$ \\
\hline Madison & 442 & $\$ 132,600$ & $\mathrm{n} / \mathrm{a}$ & & 110,500 & $\$ 29,835$ & $\$ 162,435$ & 18,000 & $\$ 313,500$ \\
\hline Orlando & 278 & $\$ 83,400$ & $\mathrm{n} / \mathrm{a}$ & & 69,500 & $\$ 18,765$ & $\$ 102,165$ & 20,000 & $\$ 188,500$ \\
\hline Toho Water Authority & 767 & $\$ 230,100$ & $\mathrm{n} / \mathrm{a}$ & & 191,750 & $\$ 51,773$ & $\$ 281,873$ & 52,000 & $\$ 523,250$ \\
\hline Pembroke Pines & 713 & $\$ 213,900$ & 410 & $\$ 41,000$ & 178,250 & $\$ 48,128$ & $\$ 303,028$ & 24,000 & $\$ 510,750$ \\
\hline Gainesville Regional & 688 & $\$ 206,400$ & $\mathrm{n} / \mathrm{a}$ & & 172,000 & $\$ 46,440$ & $\$ 252,840$ & 53,000 & $\$ 463,000$ \\
\hline Pinellas & 72 & $\$ 21,600$ & $\mathrm{n} / \mathrm{a}$ & & 18,000 & $\$ 4,860$ & $\$ 26,460$ & 16,920 & $\$ 37,080$ \\
\hline
\end{tabular}

Based on the findings from the inflow and midnight investigations, Table 4 outlines the estimated costs for cleaning, televising, lining and other repairs on the sewer system (not including lateral breaks). The effort to correct inflow is similar to the cost of televising the entire system. However, the inflow correction reduces flows into the wastewater plant more than just televising, yielding substantial annual reduction is costs for treatment. The present worth of the savings over a 10 years period is shown in Table 5, justifying the inflow removal approach. Note that the system will continue to deteriorate, so after 10 years the process should be repeated. 
Table 4. Comparison of annual savings.

\begin{tabular}{|c|c|c|c|c|c|c|c|c|}
\hline Location & $\begin{array}{l}\text { Est Cost } 2020 \\
\text { for all repairs in } \\
\text { Gravity Main }\end{array}$ & $\begin{array}{l}\text { Total Cost for } \\
\text { Corrections in } \\
\text { Area Studied }\end{array}$ & $\begin{array}{l}\text { Cost w/o } \\
\text { Inflow } \\
\text { Effort }\end{array}$ & $\begin{array}{l}\text { infiltration } \\
\text { Est Flow } \\
(\mathrm{gpm})\end{array}$ & $\begin{array}{l}\text { infiltration Est } \\
\text { Flow (gpm) } \\
\text { Saved w Inflow } \\
\text { Removal }\end{array}$ & $\begin{array}{c}\text { infiltration Est } \\
\text { Flow (gpm) } \\
\text { w/o Inflow } \\
\text { Removal }\end{array}$ & $\begin{array}{c}\text { Annual } \\
\text { Savings/1000g } \\
\text { w Inflow } \\
\text { Reduction }\end{array}$ & $\begin{array}{c}\text { Annual } \\
\text { Savings/1000g } \\
\text { w/o Inflow } \\
\text { Reduction }\end{array}$ \\
\hline $\begin{array}{c}\text { Hallandale } \\
\text { Beach }\end{array}$ & $\$ 2,112,000$ & $\$ 2,542,680$ & $\$ 2,407,320$ & 1400 & 840 & 560 & $\$ 1,314,000$ & $\$ 876,000$ \\
\hline Dania Beach & $\$ 990,000$ & $\$ 1,339,598$ & $\$ 1,193,153$ & 800 & 480 & 320 & $\$ 750,857$ & $\$ 500,571$ \\
\hline Davie & $\$ 946,000$ & $\$ 1,284,100$ & $\$ 1,254,900$ & 1350 & 810 & 540 & $\$ 1,267,071$ & $\$ 844,714$ \\
\hline Clewiston & $\$ 1,826,000$ & $\$ 2,153,245$ & $\$ 2,026,255$ & 500 & 300 & 200 & $\$ 469,286$ & $\$ 312,857$ \\
\hline $\begin{array}{c}\text { Brunswick } \\
\text { JWSC }\end{array}$ & $\$ 1,540,000$ & $\$ 2,271,368$ & $\$ 2,179,383$ & 350 & 210 & 140 & $\$ 328,500$ & $\$ 219,000$ \\
\hline Madison & $\$ 396,000$ & $\$ 558,435$ & $\$ 547,065$ & 100 & 60 & 40 & $\$ 93,857$ & $\$ 62,571$ \\
\hline Orlando & $\$ 440,000$ & $\$ 542,165$ & $\$ 526,335$ & 400 & 240 & 160 & $\$ 375,429$ & $\$ 250,286$ \\
\hline $\begin{array}{c}\text { Toho Water } \\
\text { Authority }\end{array}$ & $\$ 1,144,000$ & $\$ 1,425,873$ & $\$ 1,385,378$ & 325 & 195 & 130 & $\$ 305,036$ & $\$ 203,357$ \\
\hline $\begin{array}{c}\text { Pembroke } \\
\text { Pines }\end{array}$ & $\$ 528,000$ & $\$ 831,028$ & $\$ 735,723$ & 200 & 120 & 80 & $\$ 187,714$ & $\$ 125,143$ \\
\hline $\begin{array}{c}\text { Gainesville } \\
\text { Regional }\end{array}$ & $\$ 1,166,000$ & $\$ 1,418,840$ & $\$ 1,376,160$ & 1700 & 1020 & 680 & $\$ 1,595,571$ & $\$ 1,063,714$ \\
\hline Pinellas & $\$ 372,240$ & $\$ 398,700$ & $\$ 382,860$ & 50 & 0.6 & 0.4 & $\$ 939$ & $\$ 626$ \\
\hline
\end{tabular}

Net InI savings.

Table 5. Present worth of improvements and net savings.

\begin{tabular}{cccccc}
\hline Location & $\begin{array}{c}\text { Payback } \\
\text { period } \\
\text { w inflow } \\
\text { Removal }\end{array}$ & $\begin{array}{c}\text { Payback } \\
\text { period w/o } \\
\text { inflow } \\
\text { Removal }\end{array}$ & $\begin{array}{c}\text { Net Present } \\
\text { Value over 10 } \\
\text { years w inflow } \\
\text { Removal }\end{array}$ & $\begin{array}{c}\text { Net Present } \\
\text { Value over } \\
\text { 10 years w/o } \\
\text { inflow Removal }\end{array}$ & $\begin{array}{c}\text { Net Savings } \\
\text { w inflow } \\
\text { Correction }\end{array}$ \\
\hline Hallandale Beach & 1.9 & 2.7 & $\$ 10,657,717$ & $\$ 7,105,145$ & $\$ 3,552,572$ \\
Dania Beach & $\mathbf{1 . 8}$ & 2.4 & $\$ 6,090,124$ & $\$ 4,060,083$ & $\$ 2,030,041$ \\
Davie & $\mathbf{1 . 0}$ & $\mathbf{1 . 5}$ & $\$ 10,277,084$ & $\$ 6,851,390$ & $\$ 3,425,695$ \\
Clewiston & $\mathbf{4 . 6}$ & $\mathbf{6 . 5}$ & $\$ 3,806,328$ & $\$ 2,537,552$ & $\$ 1,268,776$ \\
Brunswick JWSC & $\mathbf{6 . 9}$ & $\mathbf{1 0 . 0}$ & $\$ 2,664,429$ & $\$ 1,776,286$ & $\$ 888,143$ \\
Madison & $\mathbf{5 . 9}$ & $\mathbf{8 . 7}$ & $\$ 761,266$ & $\$ 507,510$ & $\$ 253,755$ \\
Orlando & $\mathbf{1 . 4}$ & $\mathbf{2 . 1}$ & $\$ 3,045,062$ & $\$ 2,030,041$ & $\$ 1,015,021$ \\
Toho Water Authority & $\mathbf{4 . 7}$ & $\mathbf{6 . 8}$ & $\$ 2,474,113$ & $\$ 1,649,409$ & $\$ 824,704$ \\
Pembroke Pines & $\mathbf{4 . 4}$ & $\mathbf{5 . 9}$ & $\$ 1,522,531$ & $\$ 1,015,021$ & $\$ 507,510$ \\
Gainesville Regional & $\mathbf{0 . 9}$ & $\mathbf{1 . 3}$ & $\$ 12,941,514$ & $\$ 8,627,676$ & $\$ 4,313,838$ \\
Pinellas & $\mathbf{0 . 2}$ & $\mathbf{0 . 4}$ & $\$ 7613$ & $\$ 5075$ & $\$ 2538$ \\
\hline
\end{tabular}

The next step was to compare systems to determine if there were similarities or differences between the system in the southeast that had pursued most of the prior steps. Table 6 outlines statistics used to evaluate the pipe conditions. The flows 
Table 6. Statistics representing extent of repairs needed.

\begin{tabular}{cccc}
\hline Location & $\begin{array}{c}\text { Cost (000s)/gpm } \\
\text { of flow }\end{array}$ & Flow/Manhole & $\begin{array}{c}\text { Flow (gpm)/1000 ft } \\
\text { of pipe }\end{array}$ \\
\hline Hallandale Beach & 1.71 & 1.28 & 14.58 \\
Dania Beach & 1.50 & 1.00 & 17.78 \\
Davie & 1.95 & 0.96 & 17.91 \\
Clewiston & 3.80 & 0.61 & 6.02 \\
Brunswick JWSC & 8.57 & 0.18 & 5.00 \\
Madison & 5.00 & 0.25 & 5.56 \\
Orlando & 3.75 & 1.60 & 20.00 \\
Toho Water Authority & 12.31 & 0.42 & 6.25 \\
Pembroke Pines & 12.50 & 0.28 & 8.33 \\
Gainesville Regional & 2.06 & 2.43 & 32.08 \\
Pinellas & 50.00 & 0.01 & 0.1 \\
\hline
\end{tabular}

per manhole and per 1000 gallon of leakage were evaluated for the piping system. These variables, along with those in Table 1, were then used to generate Table 7 and the correlation analysis in Table 8 (noting that certain variables that lacked information or were present only in one or two utilities were not useful to the PC analysis). Note that from the correlation analysis, little can be gleaned as the data is poorly correlated. Using the PCA analysis, the Scree plot (Figure 22) shows that four Factors make up $80 \%$ of the variability. Table 9 indicates the F1 is made up of flow and flow data. F2 is created with system size and the water table. F3 relates to laterals. F4 relates to pipe type and cost. Since the majority of pipe is vitrified clay and the size of the system relates to flow, these two factors were of no surprise. However, water table and laterals were of more interest. The varimax rotation confirmed these findings (Figure 23).

Linear and logistic regression was applied. The standardized coefficients were similar, which was not unexpected (compare Figure 24 and Figure 25). The linear regression plot shows that the model provided a good separation between the actual and projected likelihood of lateral issues (see Figure 26). The logistic regression process indicated that the model would correctly predict lateral issues over $80 \%$ of the time (see Table 10 ). The model was $100 \%$ accurate at predicting issues resulting from high water tables (see Table 11) but was actually better at predicting a high-water table, than predicting a lower water table.

\section{Conclusion}

So the questions to answer with this investigation were whether:

- Inflow could be estimated pump run time data;

- Infiltration could be estimated using run time data;

- Inflow methods would work;

- Leaky pipes could be identified;

- Similar systems could point to similar defects; 


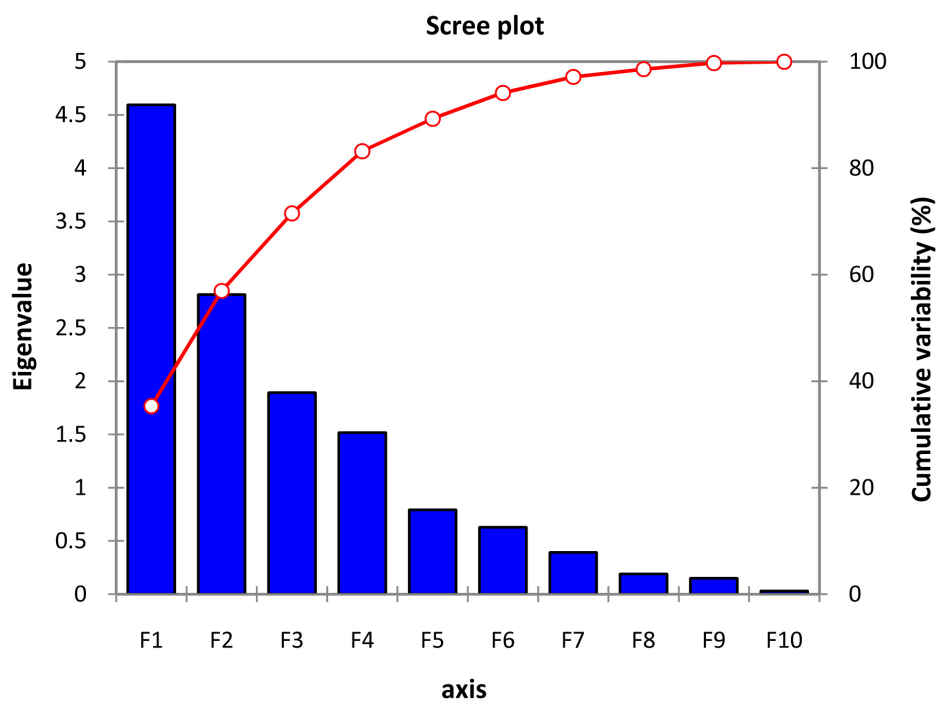

Figure 22. Scree plot.

Table 7. Variables for PCA and regression analysis.

\begin{tabular}{|c|c|c|c|c|c|c|c|c|c|c|c|c|c|}
\hline Location & Manholes & $\begin{array}{l}\text { VC } \\
\text { Pipe }\end{array}$ & PVC & $\begin{array}{l}\text { ABS } \\
\text { Truss }\end{array}$ & $\begin{array}{c}\text { Relative } \\
\text { Age of } \\
\text { Pipe }\end{array}$ & $\begin{array}{l}\text { WT } \\
\text { High }\end{array}$ & $\begin{array}{l}\text { Pipe } / \% \\
\text { to review }\end{array}$ & $\begin{array}{c}\text { Cost } \\
(000 s)\end{array}$ & $\begin{array}{c}\text { Cost } \\
(000 \mathrm{~s}) / \mathrm{gpm} \\
\text { of flow }\end{array}$ & Flow/Manhole & $\begin{array}{c}\text { Flow } \\
(\mathrm{gpm}) / 1000 \mathrm{ft} \\
\text { of pipe }\end{array}$ & Flow & $\begin{array}{l}\text { lateral } \\
\text { issues }\end{array}$ \\
\hline Hallandale Beach & 1097 & 100 & 0 & 0 & 50 & 1 & 96,000 & 2400 & 1.714 & 1.276 & 14.583 & 1400 & 1 \\
\hline Dania Beach & 800 & 100 & 0 & 0 & 50 & 1 & 45,000 & 1200 & 1.500 & 1.000 & 17.778 & 800 & 0 \\
\hline Davie & 800 & 60 & 40 & 0 & 45 & 0 & 43,000 & 1500 & 1.948 & 0.963 & 17.907 & 1350 & 0 \\
\hline Clewiston & 814 & 90 & 10 & 0 & 50 & 1 & 83,000 & 2400 & 3.800 & 0.614 & 6.024 & 500 & 0 \\
\hline Brunswick JWSC & 2000 & 90 & 10 & 0 & 65 & 1 & 70,000 & 3000 & 8.571 & 0.175 & 5.000 & 350 & 1 \\
\hline Madison & 400 & 90 & 0 & 10 & 60 & 0 & 18,000 & 0 & 5.000 & 0.250 & 5.556 & 0 & 1 \\
\hline Orlando & 250 & 100 & 0 & 0 & 55 & 0 & 20,000 & 1500 & 3.750 & 1.600 & 20.000 & 400 & 0 \\
\hline $\begin{array}{c}\text { Toho Water } \\
\text { Authority }\end{array}$ & 767 & 100 & 0 & 0 & 45 & 1 & 52,000 & 4000 & 12.308 & 0.424 & 6.250 & 325 & 1 \\
\hline Pembroke Pines & 713 & 50 & 50 & 0 & 55 & 1 & 24,000 & 2500 & 12.500 & 0.281 & 8.333 & 200 & 1 \\
\hline Gainesville Regional & 700 & 50 & 50 & 0 & 55 & 0 & 53,000 & 3500 & 2.059 & 2.429 & 32.075 & 1700 & 1 \\
\hline Pinellas & 72 & 100 & 0 & 0 & 60 & 1 & 10,000 & 50 & 50.000 & 0.014 & 0.100 & 1 & 0 \\
\hline
\end{tabular}

Table 8. Correlation of variables.

\begin{tabular}{ccccccccc}
\hline Variables & Manholes & VC Pipe & PVC & $\begin{array}{c}\text { Relative } \\
\text { Age of Pipe }\end{array}$ & $\begin{array}{c}\text { WT } \\
\text { High }\end{array}$ & $\begin{array}{c}\text { lateral } \\
\text { issues }\end{array}$ & $\begin{array}{c}\text { Flow/Manhole } \\
\text { Flow (gpm)/1000 ft } \\
\text { of pipe }\end{array}$ \\
\hline Manholes & 1.000 & -0.046 & 0.079 & 0.144 & 0.359 & 0.415 & -0.097 & -0.050 \\
VC Pipe & -0.046 & 1.000 & -0.990 & 0.052 & 0.366 & -0.253 & -0.297 & -0.438 \\
PVC & 0.079 & -0.990 & 1.000 & -0.098 & -0.298 & 0.206 & 0.327 & 0.462 \\
Relative Age of Pipe & 0.144 & 0.052 & -0.098 & 1.000 & -0.014 & 0.246 & -0.278 & -0.294 \\
WT High & 0.359 & 0.366 & -0.298 & -0.014 & 1.000 & 0.069 & -0.532 & -0.577 \\
lateral issues & 0.415 & -0.253 & 0.206 & 0.246 & 0.069 & 1.000 & -0.023 & -0.022 \\
Flow/Manhole & -0.097 & -0.297 & 0.327 & -0.278 & -0.532 & -0.023 & 1.000 & 0.959 \\
Flow (gpm)/1000 ft of pipe & -0.050 & -0.438 & 0.462 & -0.294 & -0.577 & -0.022 & 0.959 & 1.000 \\
\hline
\end{tabular}



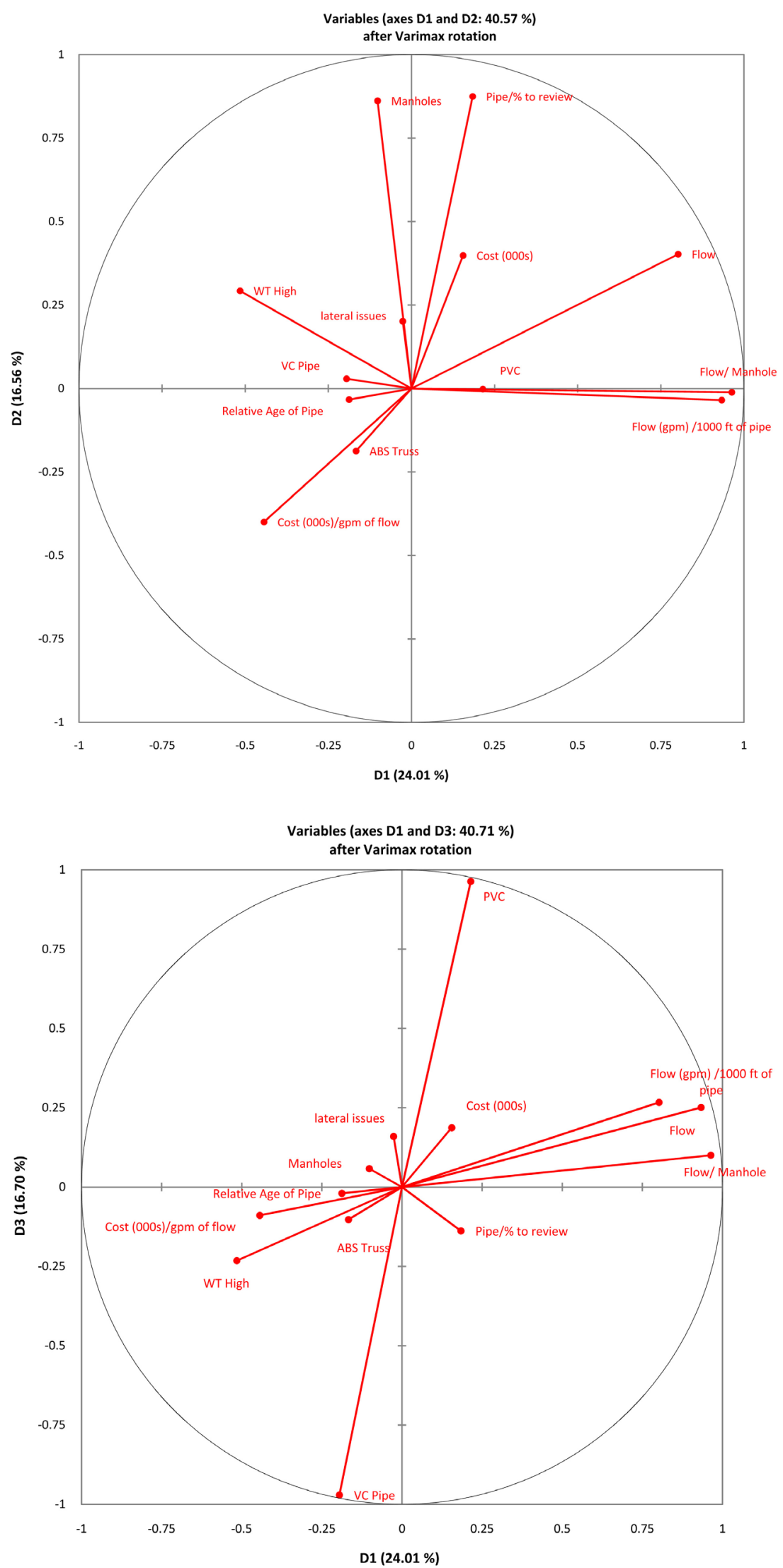

Figure 23. After varimax rotation. 


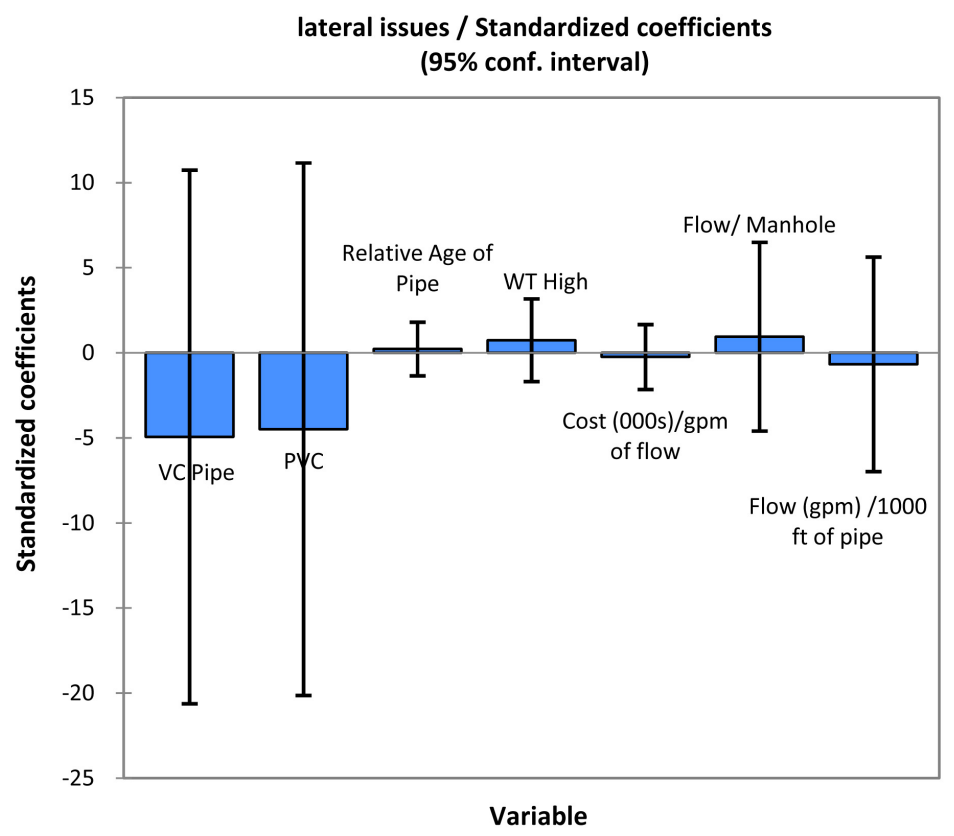

Figure 24. Standardized coefficents for linear regression.

Table 9. Factor make-up.

\begin{tabular}{ccccc}
\hline & F1 & F2 & F3 & F4 \\
\hline Manholes & 0.141 & 0.454 & 0.223 & 0.139 \\
VC Pipe & -0.272 & 0.191 & -0.407 & 0.350 \\
PVC & 0.291 & -0.152 & 0.355 & -0.417 \\
ABS Truss & -0.176 & -0.238 & 0.299 & 0.529 \\
Relative Age of Pipe & -0.206 & -0.038 & 0.409 & 0.097 \\
WT High & -0.159 & 0.478 & -0.085 & -0.266 \\
Pipe/\% to review & 0.223 & 0.445 & -0.124 & 0.198 \\
Cost (000s) & 0.290 & 0.348 & 0.123 & -0.119 \\
Cost (000s)/gpm of flow & -0.321 & -0.038 & -0.001 & -0.451 \\
Flow/Manhole & 0.381 & -0.192 & -0.186 & 0.124 \\
Flow (gpm)/1000 ft of pipe & 0.398 & -0.230 & -0.117 & 0.078 \\
Flow & 0.416 & -0.017 & -0.152 & 0.036 \\
lateral issues & 0.093 & 0.195 & 0.541 & 0.214 \\
\hline & & & & \\
\hline & & & &
\end{tabular}

Table 10. Classification table for the estimation sample (variable lateral issues).

\begin{tabular}{ccccc}
\hline from/to & 0 & 1 & Total & $\%$ correct \\
\hline 0 & 4 & 1 & 5 & $80.00 \%$ \\
1 & 1 & 5 & 6 & $83.33 \%$ \\
Total & 5 & 6 & 11 & $81.82 \%$ \\
\hline
\end{tabular}


Cost (000s)/gpm of flow / Standardized coefficients (95\% conf. interval)

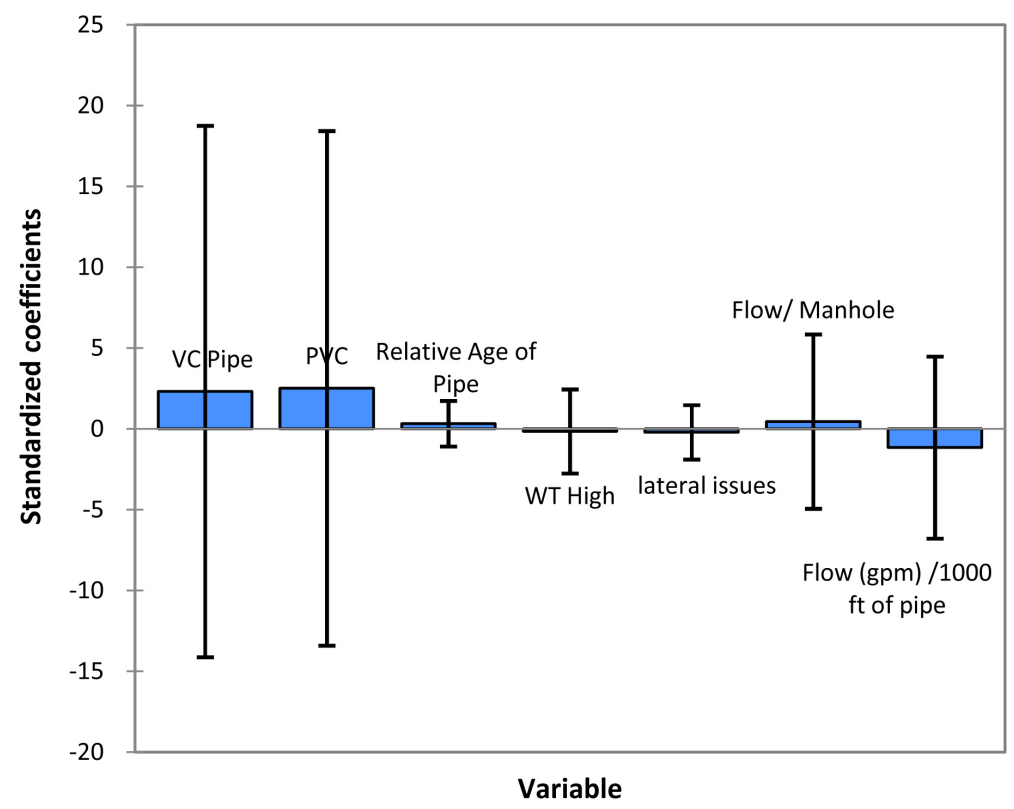

Figure 25. Standardized coefficents for logistic regression.

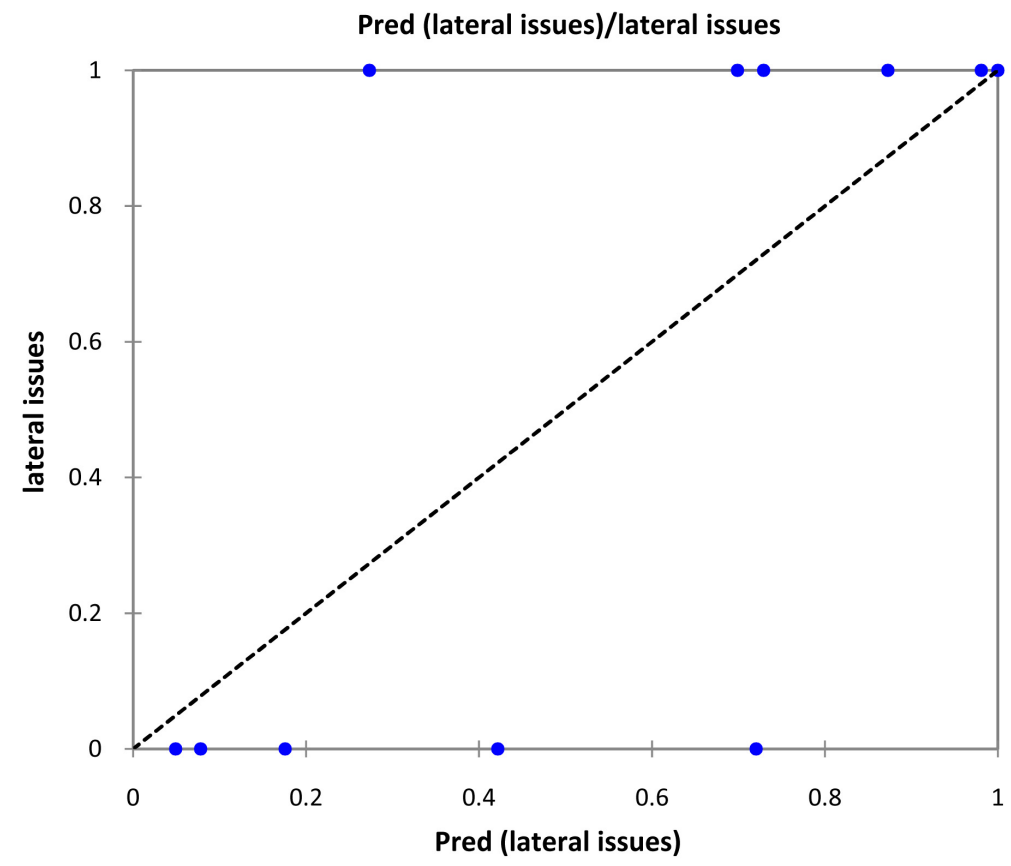

Figure 26. Prediction of lateral issues by linear regression.

Table 11. Classification table for the estimation sample (Variable WT High).

\begin{tabular}{ccccc}
\hline from/to & 0 & 1 & Total & $\%$ correct \\
\hline 0 & 4 & 0 & 4 & $100.00 \%$ \\
1 & 0 & 7 & 7 & $100.00 \%$ \\
Total & 4 & 7 & 11 & $100.00 \%$ \\
\hline
\end{tabular}


The answer to the first four of these questions was a definitive yes. Rainfall and flows correlate in an increasing graph when inflow is present and results can demonstrate noticeable change when the process described herein is pursued. Likewise, groundwater and flows are related once inflow is removed. Identifying where the infiltration is occurring can be accomplished cost-effectively with a midnight investigation. Damaged lateral connections are thought to be a major contributing factor to infiltration into several of the studied sewer systems.

The inflow and infiltration savings calculations can be used to calculate the cost savings. For example, for the service area that consisted of 797 manholes, the costs to enact fixes to 25 manholes, sealing all 797 manholes, 797 dishes, repairs to over 200 public inflow openings, identifying over 300 private connections, two smoke test events, and one-midnight run was $\$ 472,000$. The savings was $18 \mathrm{MGY}(\$ 55,044 / \mathrm{yr}$ in treatment costs). Since only 20 percent of the pipe was identified for televising, they saved over $\$ 550,000$ on the televising and lining portion off their lining program. The $\$ 772,000$ lining contract saved almost $\$ 270,000$ per year in treatment costs, yielding a payback of less than four years for the project.

A similar analysis was created for all the utilities in 2020 dollars. This effort has shown that investment in inflow, helps reduce the investment in infiltration reduction by the utility, and should provide the utility with some confidence that it will see reductions in inflow to the wastewater treatment plant, and reductions in its operating costs by using this protocol. The results show that inflow is separate from infiltration, that the peaks in flows are inflow and can be removed relatively easily, that the costs are reasonable and the solutions relatively simple. Getting the right technology and specifications is important.

For the final question, the results are mixed. Some information can be gleaned, but the similarities between systems decreased the potential variability that the statistical analyses used to identify operations factors. Statistical methods were able to identify high water and lateral issues as critical issues on these systems. The methods can be utilized at other utilities to help guide them to addressing the critical issues first as opposed to the traditional pipe lining solutions that often ignore the lateral and inflow issues that plague utility managers.

Further efforts should be undertaken in three areas:

1) Determination of groundwater impacts on flows.

2) Determination of inflow risks to utility operations.

3) Comparison of major issues between utilities to add data points to the statistical analysis.

4) Review the data to determine if added variables could be useful in identifying at the risk areas.

\section{Conflicts of Interest}

The author declares no conflicts of interest regarding the publication of this paper. 


\section{References}

Bloetscher, F. (2008). Water Basics for Decision Makers: What Local Officials Need to Know about Water and Wastewater Systems. America Water Works Association.

Bloetscher, F. (2009). City of Dania Beach SSES Memo to D. Orlando. Public Utility Management and Planning Services Inc.

Bloetscher, F. (2011). Utility Management for Water and Wastewater Operators. American Water Works Association.

Bloetscher, F. (2015). Town of Dave. Public Utility Management and Planning Services Inc.

Bloetscher, F. (2017a). Hallandale Beach SSES. Public Utility Management and Planning Services Inc.

Bloetscher, F. (2017b). Gainesville, Regional Utility Midnight Investigation. Public Utility Management and Planning Services Inc.

Bloetscher, F. (2017c). Toho Water Authority Midnight Investigation. Public Utility Management and Planning Services Inc.

Bloetscher, F. (2018a). Fort DeSoto Midnight Investigation. Public Utility Management and Planning Services Inc.

Bloetscher, F. (2018b). Clewiston SSES. Public Utility Management and Planning Services Inc.

Bloetscher, F. (2018c). City of Madison SSES. Public Utility Management and Planning Services Inc.

Bloetscher, F. (2019). Brunswick Joint Water Sewer Commission, Midnight Investigation. Public Utility Management and Planning Services Inc.

Bloetscher, F. (2020a). Pembroke Pines 2019 SSES. Public Utility Management and Planning Services Inc.

Bloetscher, F. (2020b). City of Orlando LS Area 204-206 Midnight Investigation. Public Utility Management and Planning Services Inc.

Bryan, S. (2020). Seweage Seeps into the Streets after Pipe Break in Fort Lauderdale. South Florida Sun Sentinel.

https://www.sun-sentinel.com/local/broward/fort-lauderdale/fl-ne-sewer-pipe-break-fo rt-lauderdale-20200818-swmvtkttavctpe7hwgmp3gz7y4-story.html

Bryan, S. (2020a). What's up with All the Pipe Breaks in Fort Lauderdale? South Florida Sun Sentinel.

https://www.tampabay.com/news/florida/2020/02/17/whats-up-with-all-the-pipe-break s-in-fort-lauderdale/

Lisk, B., Greenberg, E., \& Bloetscher, F. (2012). Implementing Renewable Energy at Water Utilities. Web Report \#4424, Water Research Foundation.

Marcus, N. (2020). Fort Lauderdale's Sewer Calamity Blamed on Budget Strategy that Diverted Funds Meant for Fixes. Florida Bulldog.

https://www.floridabulldog.org/2020/07/fort-lauderdale-sewer-calamity-blamed-budge t-strategy/

Merrill, S., Lukas, A., Roberts, C., Palmer, R. N., \& Van, R. N. (2004). Reducing Peak Rainfall-Derived Infiltration/Inflow Rates-Case Studies and Protocol. Water Environment Research Foundation.

https://www.waterrf.org/research/projects/reducing-peak-rainfall-derived-infiltrationi nflow-rates-case-studies-and

Rabines, A. (2015). Father-Son Wipes Creators Cleanup. Sun Sentinel Palm Beach County Edition. 
http://www.pressreader.com/usa/sun-sentinel-palm-beach-edition/20150711/28209775 0380216/TextView

Stratton-Childers, L. (2015). Flushing away the Discord. Water Environment \& Technology, 26, 24-26.

US Environmental Protection Agency (USEPA) (2005). Guide for Evaluating Capacity Management, Operation, and Maintenance (CMOM) Programs at Sanitary Sewer Collection Systems. USEPA, Washington, DC.

Wingard, R. (2015). Infiltration/Inflow: Turning a Problem into an Opportunity to Regain Capacity and Lower Operating Costs. Trenchless Technology, 25, 68 p. 